Volume 1, Number 2, 2015

\title{
Experimental Research of Speed Mode Influence on the Effectiveness of Helioroof
}

\author{
Orest Voznyak, Yurii Yurkevych, Ostap Pona, Stepan Shapoval* \\ Lviv Polytechnic National University, 12, Bandera St., Lviv, Ukraine, 79013
}

Received: April 10, 2015. Revised: June 18, 2015. Accepted: July 02, 2015.

(C) 2015 The Authors. Published by Lviv Polytechnic National University.

\begin{abstract}
Feasibility of using alternative energy sources, current state and prospects of solar energy development is analyzed. Today, it is important to improve and develop new solar panels that would reduce their costs and increase efficiency. Efficiency of helioroof in the solar heating system with forced movement of coolant is analyzed. It is shown that heat can be used effectively with roofing building material. The results of research of incoming flow of solar radiation on the helioroof are described. The change of efficiency of helioroof at different speeds and different diameters of coolant tubes, change in the coolant temperature at the inlet and outlet of helioroof and coefficient of performance of the exposure time is investigated. Graphical and analytical dependence of efficiency of helioroof depending on the speed of the coolant circuit and the diameter of the tubes circulation is established.
\end{abstract}

Keywords: helioroof; the velocity of the coolant; heating system; heat flow.

\section{Formulation of the problem}

The intensive use of traditional energy sources has led to a number of environmental problems, the most acute of which are: increase in emissions of carbon dioxide and reduction in the thickness of the ozone layer. Over the past 100 years, the concentration of carbon dioxide in the atmosphere has increased by $13 \%$. Therefore, special attention should be given to finding such heat sources, resources which would be inexhaustible and easily accessible. The use of renewable energy sources such as solar energy provides significant opportunities for heat energy can be successfully used for various domestic and technological needs. Introduction of solar heating improves the environmental situation by reducing emissions of pollutants, including combustion products of traditional forms of energy. Solar heating with conventional solar collectors is quite expensive [2, 4]. Therefore, today it is important to search for ways to reduce the cost of solar heating systems [7-9].

\section{Analysis of recent research and publications}

Solar heating systems with conventional solar collectors have a high cost and complicated design [6]. Besides, flat rectangular surface leads to large architectural and technological difficulties linking the necessary number of solar collectors on buildings [5]. Also, a significant drawback of these collectors are high manufacturing complexity and lack of efficiency of converting solar energy into heat due to heat loss. Today the walls are widely used solar collectors that simultaneously function as walling [3]. However, the disadvantage of these systems is their low efficiency and a range of intensity of heat exchange between the coolant and heat absorber panel due to a small contact area. Also, implementation of such systems requires significant investments. Today, it is important to improve and develop new solar collectors that would reduce the cost and simplify design.

\section{The main material}

The aim of this work is the study of solar roof in mechanical system depending on different speeds of coolant and different diameter of circulation tubes. The experimental unit consists of helioroof, accumulator box, source of radiation and measuring devices. The experimental unit is shown on Fig. 1.

\footnotetext{
* Corresponding author. Email address: shapovalstepan@qmail.com
} 


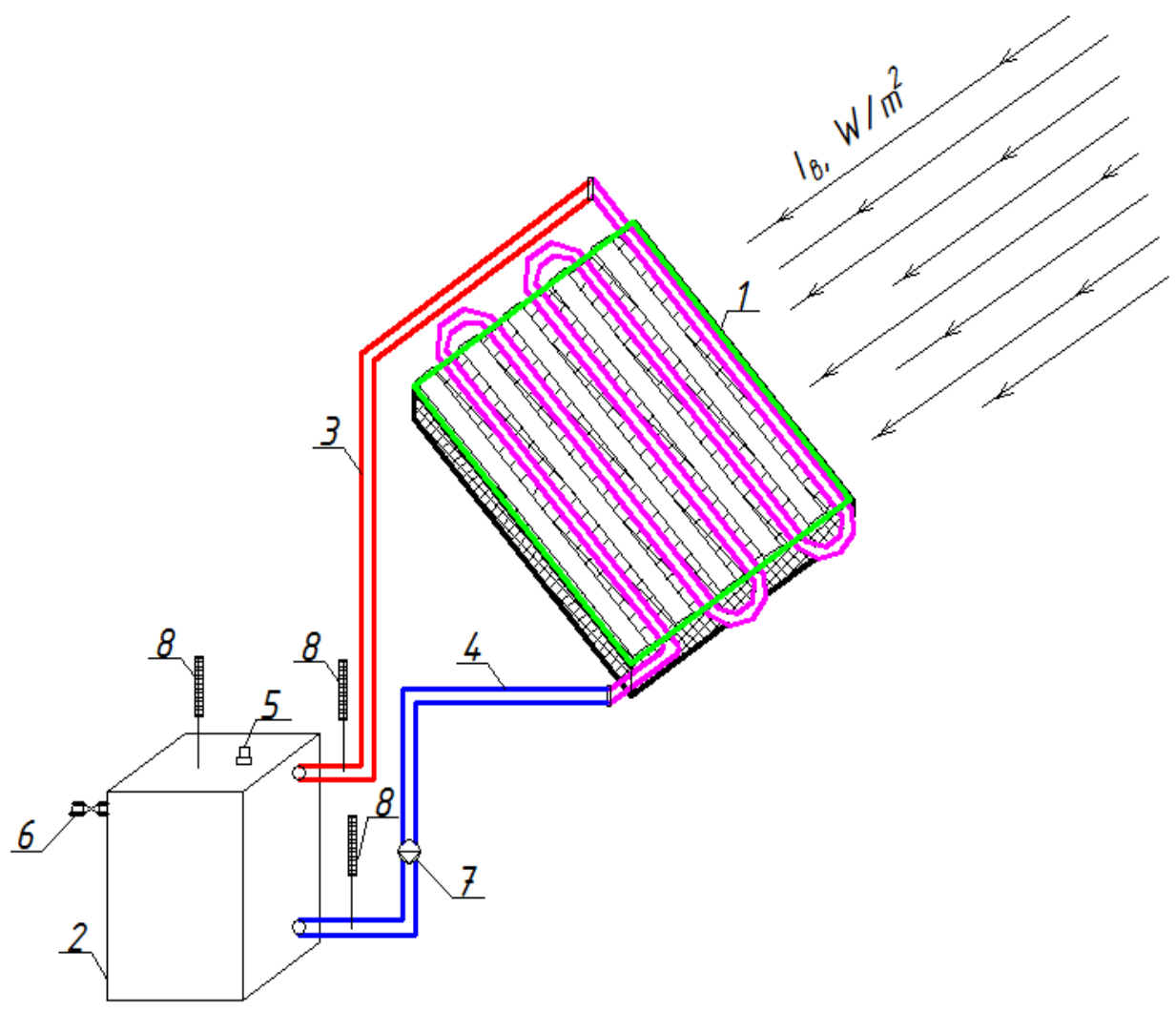

Fig. 1. Chart of the experimental unit:

1 - helioroof; 2 - a bowl of water; 3 - feeding pipeline; 4 - reverse pipeline;

5-cold water supply pipe; 6 - coolant pipe selection; 7 - pump; 8 - mercury thermometer

The experimental unit works as follows. Cold water through the cold water supply pipe 5 enters the upper a bowl of water 2. When you open the shut-off valve 7, at certain flow rate water passes through helioroof 1 , which is heated and fed into the lower accumulator box 3 . Selection of hot coolant by pipe 6 . The measurements of water temperature in the lower and upper tanks, batteries, mercury thermometers were made 4.

The intensity of the flow of energy radiated source was measured by actinometer. The temperature of water was measured at three points of the system (at the outlet of helioroof, at the entrance of helioroof, and tank-battery) by mercury thermometers. Outside temperature and its speed was measured by termoelektroanemometr TESTO 405 V1. Consumption of coolant was measured by flowmeter.

The situation was put under control to ensure that the other factors (solar energy through the window, smooth surface shading of the solar collector, etc.) did not affect the experiment. Natural air flow does not exceed $1 \mathrm{~m} / \mathrm{s}$, which did not affect the results of experiments, but made it possible to remove the excess heat during the experiment, as the result the ambient temperature during the experiment slightly increased.

Each time before the experiment started the system was filled with a portion of fresh water. We checked the hermeticity of the system at the operating pressure. The good condition of measuring devices was also tested.

The velocity of the coolant was changed from 45 to $75 \mathrm{l} /\left(\mathrm{h} \cdot \mathrm{m}^{2}\right)$. The diameter of the tube circuit is changed from 10 to $22 \mathrm{~mm}$.

After the end of the experiments, the thermal radiators were turned off, coolant circulation was stopped, heat carrier was sprinkled and system was filled with the new portion of the cooled coolant.

The research was conducted at the intensity of the heat flux of $600 \mathrm{~W} / \mathrm{m}^{2}$, which corresponds to the average intensity of solar radiation in Ukraine during the day. The angle of inclination and azimuthal angle of helioroof were $90^{\circ}$.

The results of experimental research are shown in Fig. 2-4. The results of experimental measurements of the temperature of the coolant inlet and outlet of helioroof, and the average temperature of air near the experimental setup is presented in graphical form on Fig. 2 - for the velocity of the coolant $451 /\left(\mathrm{h} \cdot \mathrm{m}^{2}\right)$, and Fig. 3 - for the velocity of the coolant $75 \mathrm{l} /\left(\mathrm{h} \cdot \mathrm{m}^{2}\right)$. 


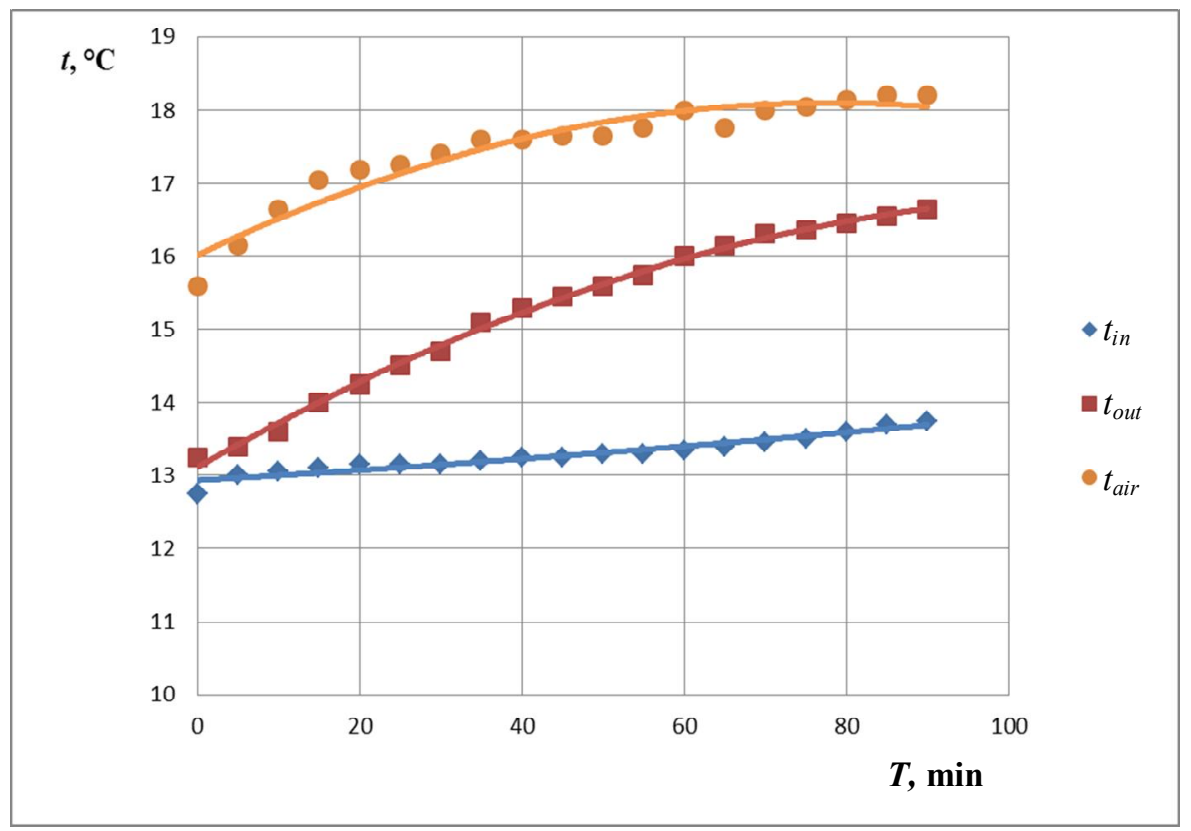

Fig. 2. The results of experimental research of helioroof at speed of coolant $45 \mathrm{l} /\left(\mathrm{h} \cdot \mathrm{m}^{2}\right)$ and diameter of circulation tubes $d=22 \mathrm{~mm}$ : $t_{i n}$ is temperature of water at the entrance of helioroof, ${ }^{\circ} \mathrm{C}$; $t_{\text {out }}$ is temperature of water at the outlet of helioroof, ${ }^{\circ} \mathrm{C}$;

$t_{\text {air }}$ is average temperature of air near the experimental setup, ${ }^{\circ} \mathrm{C}$

After analyzing experimental research shown in Fig. 2, you can see the gradual heating of the coolant throughout the experiment. Thus, at the end of the experiment, coolant temperature at the outlet of helioroof has reached $16.6^{\circ} \mathrm{C}$, so coolant was heated during the experiment to $3.9^{\circ} \mathrm{C}$.

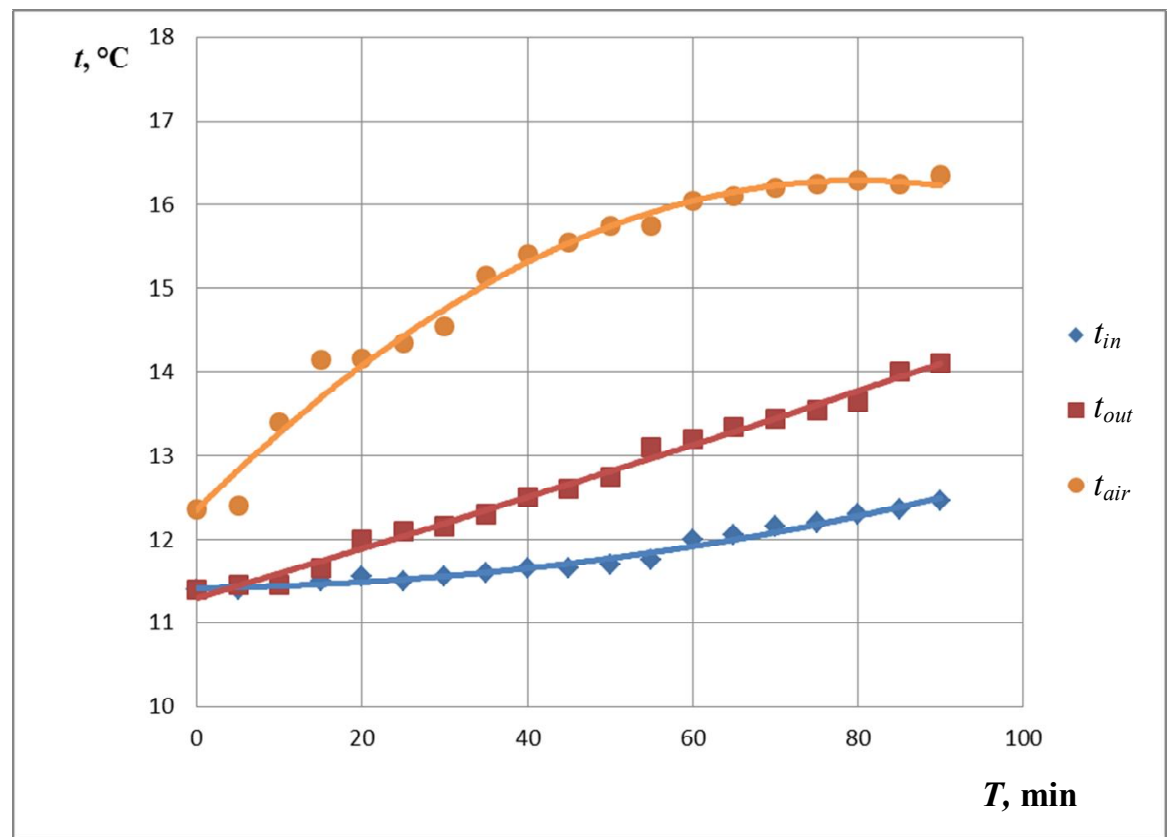

Fig. 3. The results of experimental research of helioroof at speed of coolant $75 \mathrm{l} /\left(\mathrm{h} \cdot \mathrm{m}^{2}\right)$ and diameter of circulation tubes $d=22 \mathrm{~mm}$ : $t_{i n}$ is temperature of water at the entrance of helioroof, ${ }^{\circ} \mathrm{C}$; $t_{\text {out }}$ is temperature of water at the outlet of helioroof, ${ }^{\circ} \mathrm{C}$; $t_{\text {air }}$ is average temperature of air near the experimental setup, ${ }^{\circ} \mathrm{C}$

From the graph shown in Fig. 3, we can see little change in the coolant temperature in the first 20 minutes of heating, and faster and gradually heating of coolant to the end of the experiment. In this case, the coolant was heated to $2.7^{\circ} \mathrm{C}$. 
At the velocity of the coolant of $60 \mathrm{l} /\left(\mathrm{h} \cdot \mathrm{m}^{2}\right)$ - temperature of coolant at the outlet of helioroof was $17.4{ }^{\circ} \mathrm{C}$ and coolant was heated to $4.7^{\circ} \mathrm{C}$, which is $20 \%$ higher than at the velocity of the coolant $451 /\left(\mathrm{h} \cdot \mathrm{m}^{2}\right)$.

Fig. 4 shows the dependence of the efficiency of using solar helioroof on irradiation time of the experiment at the velocity of the coolant $60 \mathrm{l} /\left(\mathrm{h} \cdot \mathrm{m}^{2}\right)$ and the velocity of the coolant $45 \mathrm{l} /\left(\mathrm{h} \cdot \mathrm{m}^{2}\right)$

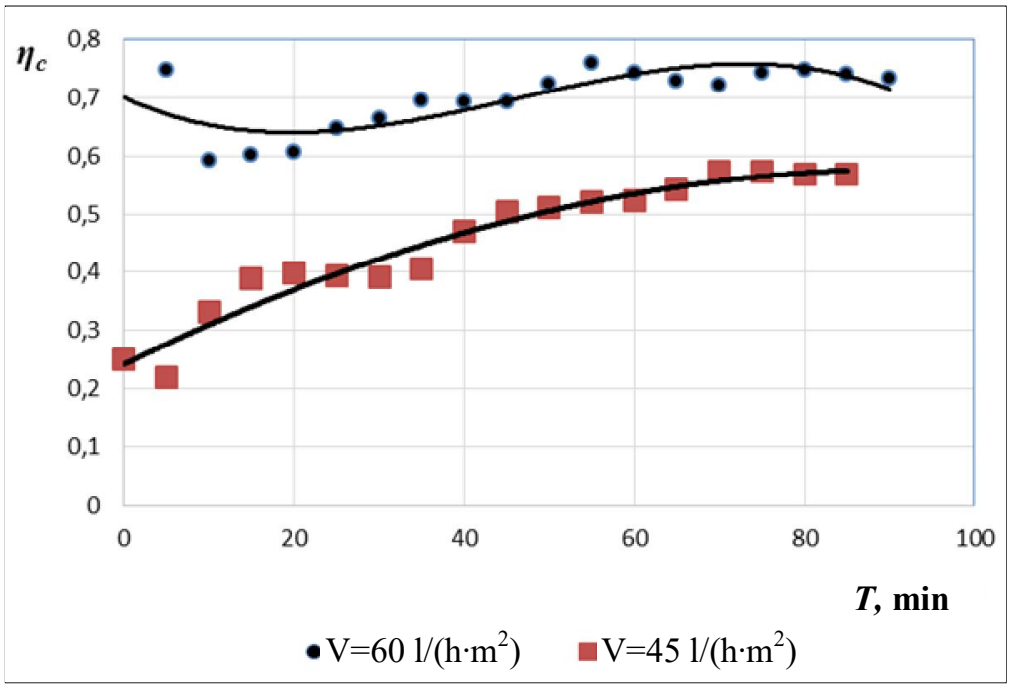

Fig. 4. Change the efficiency of solar systems using heliioroof $\eta_{s}$ depending on the irradiation time $T$, min.

After analyzing experimental results shown in Fig. 4, we see a gradual increase in efficiency of helioroof for coolant speed $60 \mathrm{l} /\left(\mathrm{h} \cdot \mathrm{m}^{2}\right)$ in the first 40 minutes of heating, followed by a slight drop. The efficiency in this case has reached $82 \%$. If the velocity of the coolant is $45 \mathrm{l} /\left(\mathrm{h} \cdot \mathrm{m}^{2}\right)$ there is a gradual increase of efficiency. Thus the average efficiency at the rate for the coolant of $60 \mathrm{l} /\left(\mathrm{h} \cdot \mathrm{m}^{2}\right)$ is $16 \%$ higher than the efficiency for the velocity of the coolant $45 \mathrm{l} /\left(\mathrm{h} \cdot \mathrm{m}^{2}\right)$.

To determine the optimal design of solar roofing, the research was conducted with a different diameter of tubes. Fig. 5 shows the experimental results when the diameter of pipes was $\mathrm{d}=10 \mathrm{~mm}$ and the velocity of the coolant was $45 \mathrm{l} /\left(\mathrm{h} \cdot \mathrm{m}^{2}\right)$.

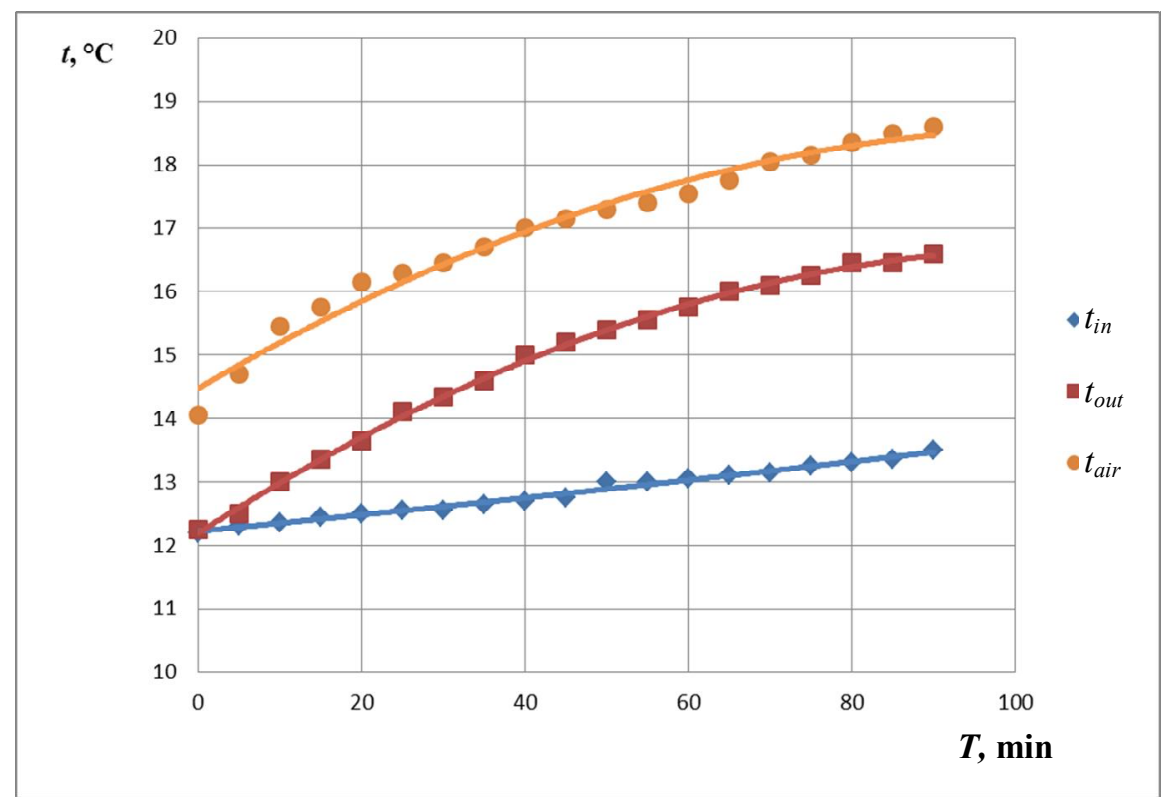

Fig. 5. The results of experimental research of helioroof at speed of coolant $75 \mathrm{l} /\left(\mathrm{h} \cdot \mathrm{m}^{2}\right)$ and diameter of circulation tubes $d=10 \mathrm{~mm}: t_{i n}$ is temperature of water at the entrance of helioroof, ${ }^{\circ} \mathrm{C}$; $t_{\text {out }}$ is temperature of water at the outlet of helioroof, ${ }^{\circ} \mathrm{C}$; $t_{a i r}$ is average temperature of air near the experimental setup, ${ }^{\circ} \mathrm{C}$ 
After analyzing the experimental results shown in Fig. 5, we see a gradual increase in coolant temperature throughout the experiment. The temperature of water at the outlet of helioroof reached value $16.6{ }^{\circ} \mathrm{C}$ and heated the coolant to $4.4{ }^{\circ} \mathrm{C}$, which is $12 \%$ more than at the same speed of the coolant and diameter of tube $22 \mathrm{~mm}$.

Based on the results, we obtained graphic of efficiency of helioroof depending on the speed of the coolant and diameter of pipe (Fig. 6):

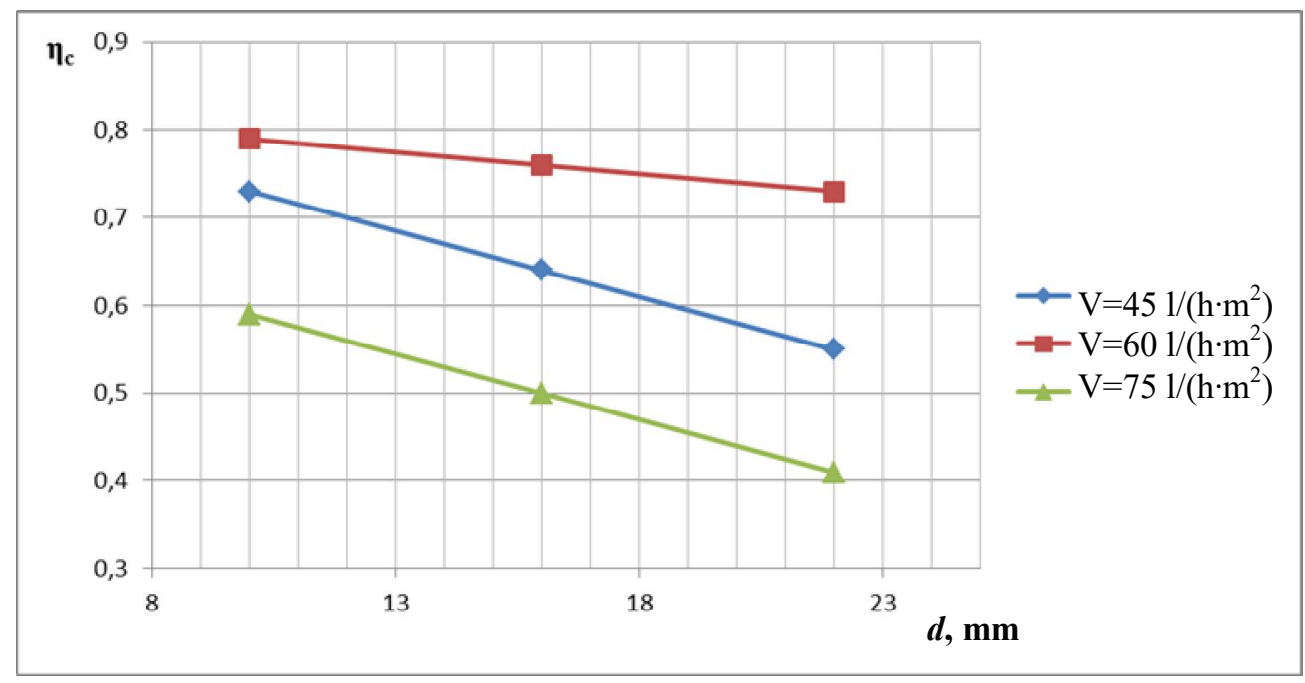

Fig. 6. Curves of helioroof efficiency versus the diameter of pipe $d$ at different speeds $V$

In the graph we can see analytical dependence of efficiency of helioroof on the speed of coolant and diameter of tubes:

$$
\eta_{\mathrm{c}}=-181.33+9.67 \cdot v-1.17 \cdot d-0.08 \cdot v^{2}+1.47 \cdot 10^{-14} \cdot d \cdot v+1.01 \cdot 10^{-13} \cdot d^{2}
$$

where $\eta_{s}$ is the efficiency of solar systems using helioroof, $\%$; $v$ is velocity of the coolant $1 /\left(\mathrm{m}^{2} \cdot \mathrm{h}\right)$; $d$ is diameter of tubes, $\mathrm{mm}$.

\section{Conclusion}

Conducted research showed effective operation of helioroof in a gravitational system of solar heating at different speeds of coolant. The temperature of water reaches the highest value at the velocity of the coolant of $601 /\left(\mathrm{h} \cdot \mathrm{m}^{2}\right)$ and is $17.4{ }^{\circ} \mathrm{C}$, which is $20 \%$ higher than at the velocity of the coolant of $45 \mathrm{l} /\left(\mathrm{h} \cdot \mathrm{m}^{2}\right)$ and $60 \%$ higher than at the speed of coolant of $75 \mathrm{l} /\left(\mathrm{h} \cdot \mathrm{m}^{2}\right)$. The average efficiency of helioroof at the speed of coolant of $60 \mathrm{l} /\left(\mathrm{h} \cdot \mathrm{m}^{2}\right)$ is $73 \%$, indicating prospects for the use of helioroof in solar heating systems. If you change the diameter of the pipe of circulation contour, the temperature of coolant at the outlet of helioroof reached value $16.6^{\circ} \mathrm{C}$ and heated the coolant to $4.4{ }^{\circ} \mathrm{C}$, at the diameter of tubes $10 \mathrm{~mm}$ which is $12 \%$ more than at the same speed of the coolant and diameter of tubes $22 \mathrm{~mm}$.

\section{References}

[1] Voznyak O. T. Basics of scientific research in civil engineering : tutorial / O. T. Voznyak, V. M. Zhelykh. - Lviv : Publ. House of LPNU, 2003. - 176 p. (in Ukrainian)

[2] Mysak Y. S. Solar power engineering : theory and practice: monograph / Y. S. Mysak, O. T. Voznyak, O. S. Datsko, S. P. Shapoval. - Lviv : Publ. House of LPNU, 2014. - 340 p. (in Ukrainian)

[3] Patent No. 103003 UA MPK (2006), F24J 2/26, F24J 2/52. Helioprofile / Strashko V. V., Sobkiv D. I., Holovchenko V. K. // Industrial property. - 2006. - No. 17. (in Ukrainian)

[4] Tvaydell D. Renewable sources of energy / D. Tvaydell, A. Ueyr; transl. from English, editor V. A. Korobkova. - M. : Enerhoatomizdat, 1990. - 391 p. (in Russian)

[5] Chaikovska Ye. Ye. Technical and economic estimation of energy-saving technology of combined heating / Ye. Ye. Chaikovska, N. F. Ishchuk // Eastern-European Journal of Enterprise Technologies. - 2011. - No 4/8 (52). - P. 45-48 (in Ukrainian) 
[6] Solar Collector: Solar energy in residential sector, hotels and small industry / [G. Wiśniewski, S. Gołębiowski, M. Grzciuk and other]. Warszawa: Medium, 2008. - 201 p. (in Polish)

[7] Voznyak O. Improvement of efficiency of plain solar collectors / O. Voznyak, V. Zhelykh, S. Shapoval // Gas, Water and Heat Engineering. Kośice, 2010. - No. 1. - P. 8-9. (in Slovak)

[8] Shapoval S. P. Efficiency of heating system based on solar collector at variation of heat flow angle / S. P. Shapoval, O. T. Voznyak, O. S. Datsko // Proceedings LPNU ["Theory and practice of civil engineering"]. - Lviv : Publ. House of LPNU, 2009. - No. 655. - P. 299-302. (in Ukrainian)

[9] Solar power engineering / [Editors Yu. N. Malevskiy, M. M. Koltun]. - Moscov : Myr, 1979. - 390 p. (in Russian)

\title{
Експериментальні дослідження впливу швидкісного режиму на ефективність геліопокрівлі
}

\author{
Орест Возняк, Юрій Юркевич, Остап Пона, Степан Шаповал
}

Національний університет “Львівська політехніка”, вул. С. Бандери, 12, м. Львів, 79013, Україна

\section{Анотація}

Проаналізовано доцільність використання альтернативних джерел енергії, сучасний стан та перспективи розвитку сонячної енергетики. Сьогодні важливим є вдосконалення та розроблення нових сонячних колекторів, які б дали змогу знизити їхню вартість та підвищити ефективність. Проаналізовано ефективність використання геліопокрівлі у системі сонячного теплопостачання з вимушеним побудженням до руху теплоносія. Показано, що можна ефективно використовувати тепло покрівельного матеріалу будівлі. Описано результати дослідження надходження сонячного випромінювання на геліопокрівлю. Досліджено зміну ефективності геліопокрівлі за різних швидкостей руху теплоносія та різних діаметрах трубок контуру циркуляції, зміну температури теплоносія на вході та виході із геліопокрівлі та коефіцієнту корисної дії від часу опромінення. Встановлено графічні та аналітичні залежності коефіцієнта корисної дії геліопокрівлі від швидкості руху теплоносія та діаметра трубок контуру циркуляції.

Ключові слова: геліопокрівля; швидкість руху теплоносія; система теплопостачання; тепловий потік. 